\title{
Abordagem Transdisciplinar ao Paciente em Cuidados Paliativos
}

\author{
Cavalcante, Luciana Suelly Barros; Saporetti, Luis Alberto; Takara, Livia; Costa, \\ Jozinete Xavier da; Carvalho, Ricardo Tavares de \\ Hospital das Clínicas da Faculdade de Medicina da Universidade de São Paulo - \\ luciana.cavalcante@hc.fm.usp.br
}

Introdução: a abordagem de pacientes com insuficiência cardíaca em Cuidados Paliativos permanece um desafio. o objetivo deste trabalho é relatar um caso de sucesso onde a abordagem transdisciplinar propiciou uma morte digna e pacífica de uma jovem mulher. Material e métodos: Relato de Caso Resultados: a paciente RSL, de 30 anos, foi identificada como elegível para cuidados paliativos pela psicóloga da equipe quando se encontrava internada na unidade de cardiologia de um hospital de São Paulo. Nesse momento, encontrava-se com dor, anorexia, náuseas, dispnéia, quieta no leito, em posição fetal, indisponível ao contato, se recusando a maiores intervenções. Nascida em Juazeiro, Bahia, mãe de um menino de 11 anos, veio para São Paulo com seu namorado para estabelecer-se e aqui se casar com ele. ao chegar a São Paulo, foi acometida por uma miocardite viral, que rapidamente progrediu para insuficiência cardíaca, com contra indicação para transplante devido a complicações. Após a abordagem da equipe médica paliativista, foi transferida para uma enfermaria de Cuidados Paliativos onde, com adequado controle dos sintomas e acolhimento, começou a comer e expressar seus sentimentos. Durante uma reunião multiprofissional, foi pontuada sua frustração diante de sonhos não realizados, inclusive seu casamento. em dada ocasião, quando o assunto surgiu, ofereceu-se a possibilidade de realizar o casamento no hospital. Já informado e ciente da gravidade do quadro, seu companheiro aceitou a proposta. a partir disso, o trabalho da equipe envolve as diferentes áreas do hospital e realiza-se uma cerimônia completa. Nesse estágio, a paciente já se encontrava dependente de oxigênio, com falência renal e mantinha dobutamina contínua. Durante a abordagem psicológica, RSL mostravase consciente de sua gravidade e seu principal sofrimento era a dúvida se era ou não amada pelos familiares e noivo. o casamento foi realizado pelo sacerdote do hospital e os padrinhos foram uma enfermeira e um médico residente. um álbum de fotos e um vídeo foram preparados e entregues para a paciente e sua família. Após o casamento, sua condição física se deteriorou, mas sua expressão espiritual e psíquica evoluiu para aceitação profunda de sua finitude, mostrando-se consciente da iminência de sua morte e do amor mútuo entre ela e sua família. nos últimos dias de vida, estava tranquila e aceitava bem os cuidados, pedia apenas para não ter falta de ar. Antes de ser sedada teve a visita de seus familiares e de seus padrinhos de casamento. Seu filho foi abordado pela psicologia a fim de ser preparado para a perda da mãe. Conclusão: a abordagem transdisciplinar da paciente permitiu adequado controle de sintomas e do seu sofrimento psíquico e espiritual, trazendo uma ressignificação profunda de sua vida e uma morte digna. a interlocução das áreas e a elaboração conjunta de intervenções proporcionais às necessidades da paciente proporcionou a ela um cuidado integral e ativo.

Cavalcante, Luciana Suelly Barros; Saporetti, Luis Alberto; Takara, Livia; Costa, Jozinete Xavier da; Carvalho, Ricardo Tavares de. Abordagem Transdisciplinar ao Paciente em Cuidados Paliativos. In: Anais do Congresso Internacional de Humanidades \& Humanização em Saúde [= Blucher Medical Proceedings, num.2, vol.1]. São Paulo: Editora Blucher, 2014. ISSN 2357-7282

DOI 10.5151/medpro-cihhs-10363 